\title{
The Igbo-African Conceptualization of Death as a Journey and Not a Destination
}

\author{
Ignatius Nnaemeka Onwuatuegwu (Corresponding author) \\ Philosophy Department, Faculty of Arts \\ Nnamdi Azikiwe University Awka, Nigeria \\ E-mail: frig2014@gmail.com
}

\begin{abstract}
Received: September 4, $2021 \quad$ Accepted: September 20, $2021 \quad$ Published: September 21, 2021
\end{abstract}
doi:10.5296/ijch.v8i2.19033 URL: https://doi.org/10.5296/ijch.v8i2.19033

\begin{abstract}
The issue of death has engaged many thinkers in almost every epoch or era. More so, different philosophers of various cultures have varied conceptions of death as well as rendering differing definitions and interpretations of the concept. Heidegger, for instance, sees man as a being destined to die and, therefore, man lives towards death. Death, simply put in that line of thought, therefore, is the primary purpose or destination of man on earth. This idea renders everything man does on earth as a venture in futility. Nevertheless, man is a being unto immortality. Death from the Igbo-African ontological point of view is but only a vehicle with which man is conveyed to immortality. It is an unavoidable path which every single individual person must unavoidably pass through if one is to be translated and transformed into immortality. The writer in the work resorted simply to the methodological approach of expository and philosophical reflection to accomplish the goal of the study. Invariably, the conclusion that death is, therefore, not a destination but a journey is drawn.
\end{abstract}

Keywords: death, journey, destination, signs of departure, last testament

\section{General Introduction}

At various times and in various cultures and schools of thought, death has been variously defined as well as differingly interpreted. The issue of death, hence, has engendered a lot of discussions and argumentation. Notwithstanding, death up to the present moment is still something very elusive in nature.

However, in Jainistic comprehension of human existence, the moment of empirical physical existence is seen as a moment of trial in which a man is subjected to a trial of which he must 
pass before the spirit of the individual person can be allowed into a place of rest. On this Bryher noted that:

We know something of Celtic doctrine from early Welsh poetry and Breton Folklore. It seems to have had much in common with some forms of eastern thought. Life was considered as a time of trial: if its initiation was successfully passed, the spirit rested after death until the moment came for another return to earth. This continued until, after many lives some attained to the state of spiritual perfection (Bryher, 1950).

Man, therefore, is condemned to continue in this process of resting for awhile and coming back to earthly existence until one reaches the full spiritual awareness or perfection. Only, but after which man can possibly enjoy a permanent life of rest.

Admittedly, some parts of the Old Testament scriptures seem to conceive death as an annihilation or being thrown into a dungeon of darkness from where the dead shall see no more light. Hence, the psalmist summarises thus:

The dead do not praise the Lord, all those gone down into silence. It is we who bless the Lord, both now and forever (Ps. 115:17-18).

However, in some parts of the Old Testament Scriptures, there are some glimpses of hope that death is not the end of life but a temporary slumber of unconsciousness from which man still has the hope of eventual restoration to active and conscious life or re-awakening from that deep slumber of unconsciousness. Hence, Job exclaims:

I know that my redeemer lives, and that in the end he will stand on the earth. And after my skin has been destroyed, yet in my flesh I will see God; I myself will see him with my own eyes I, and not another. How my heart yearns within me! (Job 19:25-27).

In Hinduism, the Issue of life and death is considered as a continuum in which there are a continuous process of putting off the worn-out bodies and taking on new ones. Thus:

Just as a person casts off worn-out garments and puts on others that are new, even so does the embodied soul cast off worn-out bodies and take on others that are new (Radhakrishnan \& Moore, 1957)

In this view, human life becomes a mere metamorphical phenomenon or process of changing or transforming from one stage of life to another ad infinitum.

The Buddhists are instead sceptical about death and the life after. This their sceptical approach or position is obviously demonstrated in Majjhima Nikaya's quotation. Thus:

I have not elucidated that the world is eternal, and I have not elucidated that the world is not eternal. I have not elucidated that the saint exists after death, I have not elucidated that the saint both exists and does not exist after death (Majjhima, 1977). 
The ancient philosophers such as Plato, however, saw death as a liberation, an attainment of freedom from the prison in which the material body has enshackled the human person. For him, therefore, death is a so much cherished phenomenon in the human existence, which every individual person yearns and aims to attain. He thus lamented and yearned for who will deliver him from this prison which is his body, so that he can be truly free from the material shackles (Plato, 1999). Paul, the apostle of Christ Christianised Plato in this understanding in his letter to the Romans as he observes thus:

We know that all creation is groaning in labour pains even until now; and not only that, but we ourselves, who have the first fruits of the Spirit, we also groan within ourselves as we wait for adoption, the redemption of our bodies (Rom. 8:22-23).

Obviously, an Igbo-African is not uncomfortable in his material or physical body, for it is a welcome fact of human existence. However, he sees death as a necessity and an inevitable phenomenon of human passing existence on earth. He is, therefore, resilient to the reality of death and, therefore, faces death with equanimity especially when he felt that he has accomplished that for which the owner of life created him in the first place.

In this exposition, we shall focus our attention on the Igbo-African understanding of death as well as his attitude towards death. Then, emphasis will be made on the practical signs that are the premonition that death is gradually approaching. What does a good and a fulfilled Igbo-African do when it is becoming sparklingly clear that death is around the corner. With that done, the conclusion will then be drawn.

\section{Igbo-African Understanding of Death}

Death is nothing but an illusion. It can be misconstruedingly taken for an end to an individual existent. But:

Death is not the end of life. It is rather the end of one phase of life and the beginning of another (Metuh, 1999).

However, the Igbo see death simply as a necessary and an inevitable interruption of the conscious earthly existence. I. N. Onwuatuegwu is in accord with this understanding of death as he observes that ndi Igbo, nonetheless, see death not as an end of earthly existence but as an interruption of earthly dwelling (Onwuatuegwu, 2010). Death being conceived as such, necessarily implies the possibility of a continued existence somewhere and somehow as well as the idea of eventual coming back to the empirical physical world of human existence. In support of the above point, Metuh succinctly says that:

Death is not man's final end. All who die continue to live somehow after their death whichever death they suffered. Even those who received no funeral rites continue to live, but their place of abode and their statuses differ (Metuh, 1999).

At death, it is only the corporeal nature that suffers dissolution. The human person in the Igbo traditional conception is immortal. The human person as a union of soul and body, at death, is 
transformed or translated into a spirit being. Oguejiofor rightly considered this Igbo-African understanding of man as a unity of soul and body as "an out crop of the inseparability of the spiritual and the material world in Igbo conception" (Oguejiofor, 1996). As a spirit being, man is imbued with the intrinsic qualities to possibly translate into a human being, which the Igbo called reincarnation. Talbot rightly captures this, thus:

Igbo people consider death as the dissolution of one's corporeal nature. It is God's messenger which appears to the dying in the form of a skeleton with a staff with which he strikes his victim and transforms him into a spirit (Talbot, 1996).

Hence, at the moment of death, the dying man puts off the flesh, which is the material clothing with which man appears in the empirical physical world of reality. Of course, borrowing the words of Ogugua: since the world is consisting of the invisible and visible dimensions, the Igbo conceived man as a spiritual that is manifesting in a physical body (Ogugua, 2003). The human person as the unity of the soul and body, at this stripping off of the material body now assumes a new status of spirit being which must be differentiated from a pure spirit. A pure spirit is a spirit that was never a human being, but a spirit man or a spirit being is a spirit that was once a human being. Mbiti, therefore, affirms that:

It is clear that people view death paradoxically: it is a separation but not annihilation, the dead person is suddenly cut off from the human society and yet the corporate group clings to him (Mbiti, 1969).

Invariably, it is the material body that suffers putrefication in the grave while the real person as the unity of soul and body is not affected or hindered by death. This unity of soul and body is exactly what Oguejiofor called the "the conceptual inseparability of a person's body from his soul" (Oguejiofor, 1996). In that regard, man has the capacity and the capability of surviving outside the material body with which he is clothed in the physical empirical passing existence.

After the completion of the funeral rite, the spirit enters the Ndiichie, ancestral shrine, meanwhile, his Chi goes for an interview, which has aspect of a judgement (Metuh, 1991).

The funeral is necessarily performed in order to severe the dead person from the material physical world and to send him off peacefully and perfectly to the village of Ndiichie in the spiritual world of reality.

\section{Signs of Departure}

Loss of the sense of taste. At this time one might have started loosing some of one s senses like sense of sight(vision), sense of hearing, sense of feeling, and even coordination will become difficult. At this time, one is likely to have started losing focus.

Equally, the physical strength will begin to fail. To carry out certain normal day to day activities that were usually done with pleasure, will now become a hechullian task and an Achilles heel. In such a situation, the person in question will have started to lose interest in 
those things that formally used to interest him.

More so, the next stage will be the re-play of past life. At this time, one may starts to being more unconscious of one $\mathrm{s}$ immediate environment but very conscious of past and remote environment. This comes together with its accompanying forgetfulness of the immediate events, but can vividly remember and recount with accuracy past events. Those things that have gone into the subconscious mind now re-surface in the consciousness and the matters in the conscious mind tend to descend into the subconscious realm.

The dilemma and the Perplexity of life, coupled with its attendant effort to reconcile the facts of life and the issue of dying and finally leaving the world of the sensible reality is the most difficult moment in this matter of life decision making. The strange part of this stage is the experience of the chase of death (onwu ichu mmadu oso). A person in this stage can often wake up in the middle of the night and becomes afraid; that is, feeling jittery without figuring out exactly the cause or the reason for the fear.

At this point one may begin to encounter the departed as if they were not dead. He may at times be talking with the dead relatives or neighbours as if they were still alive. The scenario is what the psychologists may call negative or positive hallucinations. The opportunity of the last vision which is a clear premonition that death is around the corner, is often granted to some. This is a foretaste or a brief demonstration of what the person's life hereafter is going to look like. This last vision includes death appearing to the dying man in a physical manner. Hence, the Igbo refer to death as;

God's messenger which appears to the dying in the form of a skeleton with staff with which he strikes his victim and transforms him into a spirit (Talbot, 1996)

Those who have a favourable last vision are by that, granted the grace of serenity that unavoidably demonstrates in their physical or outward demeanour and eventual peaceful and happy death. Happy death is very expedient for an Igbo man, for it is among the necessary requirements that qualify one into the status of ancestorship. Hence, Onwuatuegwu listed as one of the requirements for ancestorship, thus:

He or she must have to die a good death. A good death implies that the diseased did not die of mysterious illness (onwu ojoo) or by accident (onwu ekwensu) or died and was buried outside his or her village (onwu nnwufu) (Onwuatuegwu, 2010).

This is because, according to Metuh, a natural death is not annihilation, rather it is conceived as something wholly positive (Metuh, 1999). Nevertheles, those with unfavourable last vision are believed to be restless, struggling and fighting even as they are dying. Some in that mood of restlessness and wrestling will even start to make negative or what may be called forced confession (isa asisa). It is considered negative and forced because the individual in question is no longer in control of their consciousness. Hence, it is considered an involuntary confession. 
By this time around, the person must have accepted the reality of death, and is thereby either ready to leave the world of material existence with equanimity, or is regretting his unfulfilled, unrealized and un-actualized existence. Little wonder Abanuka affirms that:

...the potentiality contained in one's eke (destiny) must be actualized by the individual himself, it is believed that both those who do not discover their destiny at all and those who discovered it late and were not able to fulfill it completely, must come back... to accomplish their uncompleted tasks (Abanuka, 2004).

It is at this moment that such a one with fulfilled existence usually made his or her last testament which often comes in the form of advice, admonition, instruction, direction or gratitude and blessing.

\section{Conclusion}

In Igbo-African milieu, the consciousness of the reality of death is taken for granted. Hence, the Igbo saying that a pilgrim is always aware of the fact that he must one day depart or set out to go back from where he comes from (Obiara ije nwe una). Hence;

...it.. appear that the spirit-land is man's real home. Man is essentially a spirit, who comes from the spirit realm, or pre-natal state, for a brief sojourn in this world - after which he returns. Life goes in a cyclic, alternating between the spirit-world and the visible world (Metuh, 1999).

With this in mind, therefore, they consider death as a necessary end or conclusion of life in the empirical physical world and, hence an inevitable fact of human existence. Being in this consciousness of the reality of death implies that one should avail oneself of the opportunity of the period of earthly existence to get prepared for a fulfilled end and eventual happy death. Rat can only eat someone's food when he is not awake and vigilant(Oke adi eri ihe onye mu anya) and again, a forewarned battle does not claim the life of even a crippled (Agha akaraka adi eri ngwuro). All these sayings imply that a reasonable and a vigilant person should not be taken by surprise by death. Meanwhile, an Igbo man works for a worthy living and at the same time get himself prepared for exiting the temporal world of reality (Azota ndu edobelu onwu).

Hence, the traditional Igbo people conceived death, not as a destination, but rather as a journey. This is because they believed that every single person has a double abode: the worldly dwelling and the spiritual dwelling place (Onye nosia obodo mmadu o naba obodo ттио). This idea is well articulated by Ekwunife, thus:

... Igbo world is principally a world of two interacting Realities - the spiritual and material, each impinging on the other. It is both the world of spiritual beings and the world of man with other animate and inanimate beings. In this world, the material mirrors the Sacred in different degrees (Ekwunife, 1990). 


\section{References}

Abanuka, B. (2004). Philosophy and the Igbo World. Enugu, Snaap Press Ltd.

Bryher, W. (1950). Ruan. New York, Pantheon.

Ekwunife, A. N. O. (1990). Consecration in Igbo Traditional Religion. Enugu, Snaap Press Ltd.

Job 19:25-27 New International Version.

Majjhima, N. (1977). In Head, J., \& Cranston, S. L. (Eds.), Reincarnation: The Phoenix Fire Mystery. New York, Warner Books.

Mbiti, J. S. (1969). African Religions and Philosophy. London, Heinemann.

Metuh, E. I. (1991). African Religions in Western Conceptual Schemes: The Problem of Interpretation. Nigeria, Ehindero Ltd.

Metuh, E. I. (1999). God and Man in African Religion. Enugu, Snaap Press Ltd.

Oguejiofor, J. O. (1996). Eschatology, Immorality and Igbo Philosophy of Life. Bigard Theological Studies, 16(2).

Ogugua, P. (2003). Igbo Understanding of Man: A Step to Understanding Igbo Metaphysics and Fostering a true Philosophy of life. Nigeria, Penmark Publishers.

Onwuatuegwu, I. N. (2010). The Concept of Reincarnation in Igbo Ontology: A Philosophical Appraisal. Nimo, Rex Charles and Patrick Publications.

Plato. (1999) "Phaedo" in Great Dialogues of Plato, trans. W. H. D. Rouse, New York, Signet Classics Printing.

Psalm 115: 17-18 The African Bible, Pauline Publications Africa.

Radhakrishnan, S., \& Moore, C. A. (1957). Chapter III. The Bhagavad-Gita. Walter de Gruyter GmbH.

Talbot, P. A. (1996). Tribe of the Niger Delta. Quoted in Anameze, L., Belief in Spirits and Reincarnation, a Philosophical Analysis, Enugu, CPA and Gold Production.

\section{Copyrights}

Copyright for this article is retained by the author(s), with first publication rights granted to the journal.

This is an open-access article distributed under the terms and conditions of the Creative Commons Attribution license (http://creativecommons.org/licenses/by/4.0/) 